\title{
THE MALE SOPRANO
}

\section{BY FRANCIS ROGERS}

$\mathbf{F}$

ROM the point of view of the twentieth century there is nothing in musical history more curious or harder to explain than the importance and popularity of the male soprano during the first two centuries of Italian opera seria (16001800). Nowadays, if there were a survivor of this sexless tribe, we might take an interest in him as in a freak, but should certainly consider him out of place in any dignified musical environment. Occasionally in vaudeville or minstrel shows one hears men singing in the feminine register, but, probably in all such cases, they are employing a highly developed falsetto or are passessed of excedingly light and high tenor voices. We are here concerned with the castrate soprano, who down to the close of the eighteenth century held the same exalted position in Italian opera that the tenor held in the nineteenth and still holds in the twentieth. He is now as extinct as the dodo, but the leading part that he played in the early history of the art of singing quite justifies the writing of a chapter on the rise, supremacy, and gradual disappearance of this strange being and his art.

For reasons not far to seek, much, if not most, of the history of the male soprano is shrouded in mystery; his origin is entirely obscure. Admiration for the lower notes of the human voice, both masculine and feminine, exists only where there is a considerable development of musical taste. Among primitive peoples there is an unmistakable preference for a high-pitched voice, deep tones being considered grotesque or mirth-provoking. It is possible, though not demonstrable, that the vogue of the male soprano in the early days of art singing in Europe was due to an undeveloped musical taste.

The exclusion of women from the choirs of the Roman church accounts for the introduction of male sopranos into choral singing. Boys could be substituted satisfactorily for women then, as now, but there was one drawback to their substitution-their voices were very short-lived. A boy had scarcely attained efficiency as a church singer when the process of mutation robbed him of his peculiar vocal fitness and transformed his voice into quite another organ, an octave lower in pitch and altogether masculine in timbre. One remedy for this unfortunate state of things was the use of the masculine voice in its falsetto register, but this was only partially successful, because the falsetto voice, 
even at its best, has, when emitted with only moderate power, an unpleasant, strident quality. Nevertheless, this expedient was employed in the sixteenth century, in the Papal Choir, where the two upper voice parts were sung by falsettists trained in Spain according to some special system of which nothing now is known. These "contraltini," as they were called, had superseded boy choristers.

There was another way out of the difficulty. It was long ago discovered-when or how, none can say-that when a boy is castrated mutation never takes place and his voice retains its boyish pitch and quality indefinitely. It was found also that with maturity and intelligent discipline such a voice gained greatly in volume and emotional quality. This physiological fact accounts for the entrance into musical history of the male soprano, or, as he was variously called, castrato, evirato, or musioo.

We find traces of anonymous castrati in Italy as far back as the twelfth century, but the first castrato known to us by name was a certain "Padre" Rossini, who became a member of the Papal Choir in 1601. The contraltini, who at that time were in vogue, resented his appointment 80 actively that without the backing of the Pope himself Rossini's position would have been untenable. The experiment was evidently considered a success, for by 1625 the contraltini had been completely superseded by castrati and Pope Clement VIII had declared officially that the creation of castrati for church choirs was henceforth to be held "ad honorem Dei."

Ecclesiastical music reached its climax of excellence about 1504, the year of Palestrina's death. In the same decade modern opera may with sufficient accuracy be said to have been born. It was quite natural that the new form of art should make use of the only professional singers there were, those in the choirs. The art-loving prelates were opera-mad and as the church forbade the appearance of women on the Roman stage, the castrati were transferred from their choir-stalls to the stage, where they were assigned the feminine roles in the new-born operas. It was incongruous enough for these sexless creatures to impersonate the heroines of romance and history; still more absurd was their assumption of characters so virile as those of Alexander and Roland and those even of fathers of families. However-the opera-supporting public of those faraway days overlooked such absurdities, and set the seal of its august approval on the musical efforts of the castrati.

The first male soprano of whom we have any detailed knowledge was Loreto Vittori (1588-1670). At an early age he entered 
the service of Cosimo dei Medici and took part in the Florentine operatic representations. In 1622 he became a member of the Papal Choir, but continued his operatic appearances. He was a composer and a poet, as well as a singer, and so complete was his equipment as an artist that his contemporaries set no bounds to the expression of their admiration for his many gifts.

Another famous male soprano of the 17th century was Baldasarre Ferri (1610-1680), whose professional career was one long succession of artistic triumphs. He was held in high esteem not only in Italy, his native land, but also in Poland, Germany and Sweden, where royalty showered upon him wealth and honors and the public pettod him as enthusiastically as we Amoricans feted Jenny Lind two hundred years later. All contemparary comments agree in extolling the perfection of his person, his voice and his art.

Then there was Grossi, known as "Siface" from one of his most successful roles, whose name is closely associated with some of the earlier works of Alessandro Scarlatti. He, too, was famous for the beauty of his voice and the noble expressiveness of his style. He came to England and for a time was a member of the choir of James II. Evelyn mentions in his diary hearing him with this choir in January, 1687, and also at the house of Samuel Pepys three months later.

By the end of the 17th century the place of the evirati was firmly established in the musical world. In comic opera, with its essential touch of realism, the castrato naturally could find no place; but in serious opera, the plots of which were derived from mythology, Greek, Roman or medieval history and treated according to a most unrealistic convention by such artificers as Zeno and Metastagio, the musico's ability to sing seemed to render his public oblivious of the abnormality of his personality. Inexplicable as this insensibility may seem to us of the twentieth century, we must not forget that the early fathers of opera were serious musicians striving for their ideals just as conscientiously as did Wagner and Verdi.

The public that concerned itself with opera seria was made up largely, if not altogether, of dilettanti, who then, as now, did not exact that art should hold the mirror up to nature, and when once a convention had been established and received the seal of approval of the socially elect, accepted it as one of the eternal verities of art. It was for such as these that the castrato sang. The big general public probably seldom heard him sing and knew little or nothing of the form of art in which he flourished. 
The most famous castrato in Europe in 1700 was Francesco Pistocchi (1659-1796), who had a distinguished career both as a singer and as a composer. Early in the first decade of the century he founded a school of singing in Bologna which turned out many fine singers and did much to fix the early standards of bel canto. His most celebrated pupil was Antonio Bernacchi (1690-1756), whose voice, although not of exceptional beauty, was so perfectly trained as to win for him the title of "King of Singers." He was popular in Germany, as well as in Italy, and also made two visits to England, in the course of which he sang in some of Handel's operas. As time went on his interest in rocal technique led him into an unprecedentedly florid style of singing, which he imparted to his many pupils. Before long mere virtuosity was to become the end and aim of vocal art.

Senesino (1680-1750), a contemporary of Bernacchi's; was one of the most admired singers of his time. His singing was especially well known in England, where he created a number of roles in Handel's operas. His voice was limited in compass, but of exquisite quality. His rendering of recitative was considered altogether exemplary.

Twenty years younger than Senesino was Carestini, who, according to Dr. Burney, was a "tall, beautiful, majestic" creature, whose voice, originally a soprano, later "changed into the fullest, finest and deepest counter-tenor that has ever been heard." Hasse, who knew a thing or two about singing, thought him the very best singer of his time.

One has to go back to the musical career of King David to match the romantic story of Carlo Broschi, known to fame as "Farinelli." Farinelli was born in Naples in 1705, was trained by the greatest of all singing-masters, "il Patriarca dell" Armonia," Niccold Porpora (1686-1766), and made his début in one of Porpora's own operas in Rome in 1722. Porpora devised a clever tour de force for the display of his pupil's voice and technique. There was in the orchestra a trumpeter far-famed for his virtuosity. Porpora arranged to have him play an obbligato for one of the arias assigned to the young singer, in such fashion as to bring the voice into direct comparison with the instrument. Farinelli stood the test admirably; in breath-control, in phrasing, in flexibility, in every technical detail the boy of seventeen showed himself the peer of the master of the trumpet.

Farinelli continued his studies with Porpora for two more years before he made his first tour of the Italian capitals. At Bologna he appeared in the same opera with Bernacchi, "the 


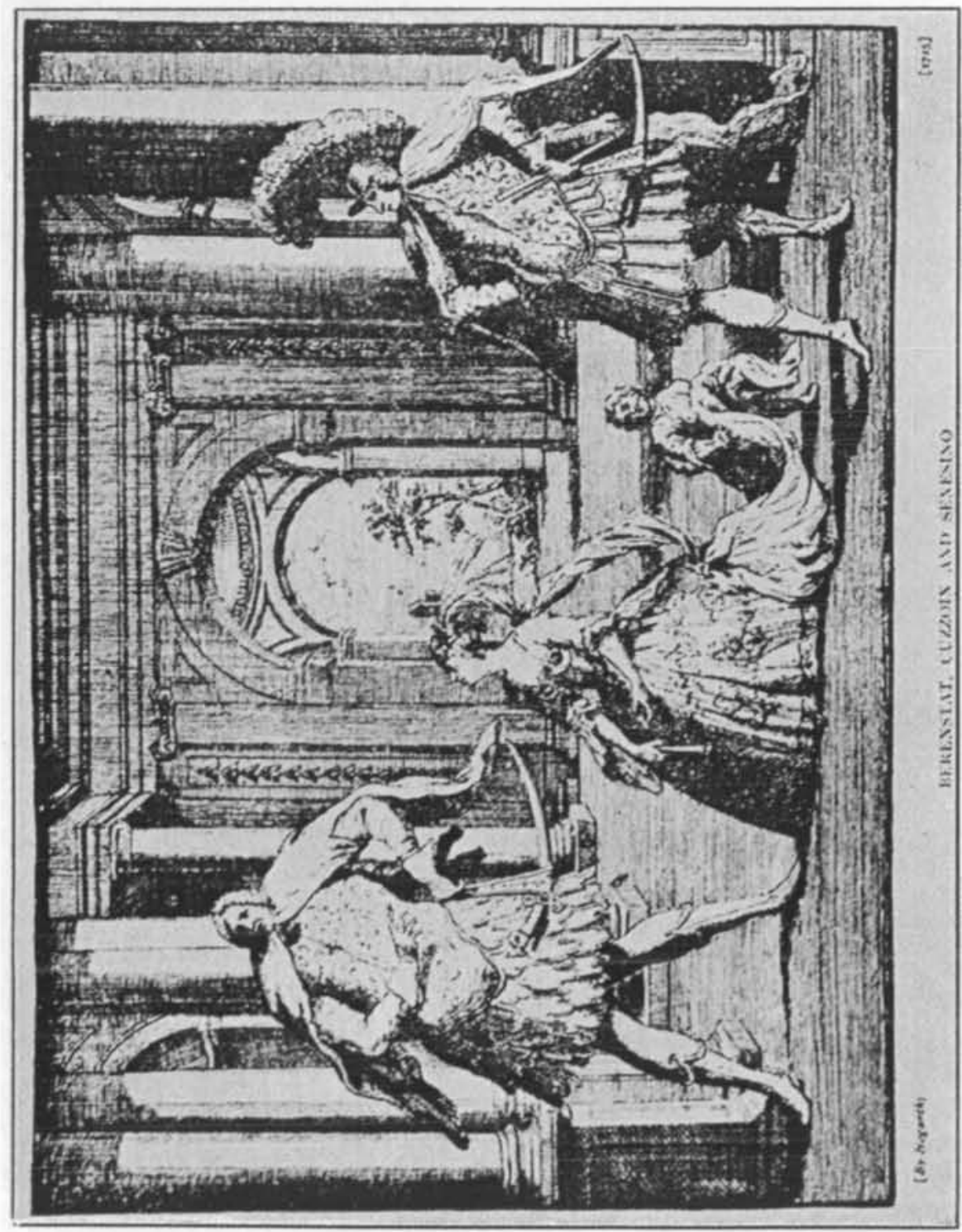


King of Singers." The event of the evening was a duo for the two castrati. Farinelli sang first, and in the manner of the time performed every vocal feat in his repertory. Then Bernacchi stept forward and repeated without mistake or blemish every note that the younger man had sung, throwing in, for good measure, some vocal pyrotechnics of his own invention. The honors of the contest rested with Bernacchi, who graciously. acceded to Farinelli's request that he accept him as a pupil and impart to him some of the secrets of his wonderful art.

When Farinelli arrived in Vienna in $\mathbf{1 7 9 1}$ he was generally considered the finest vocalist in Europe, but there was still something lacking in his voice. The Emperor said to him: "Hitherto you have aroused amazement by your wonderful facility; why not now try to touch the hearts of your hearers by the simplicity and truth of your musical expression?" Farinelli accepted the imperial suggestion and acted upon it with happy results.

He came to London three years later as a member of Porpora's opera company, the rival of Handel's. The first note he uttered was so lovely that the audience interrupted him with applause that lasted several minutes. London went simply mad. over him. In Hogarth's "Rake's Progress" is to be found a reference to one authentic scene of his career, in which a noble lady nearly fell from her box crying, "One God; one Farinelli!"

His face was pleasing, rather than handsome; he was "as tall as a giant and as thin as a shadow, therefore, if he had grace, it could be only of a sort to be envied by a penguin or a spider." Possibly because of the ungainliness of his person, he stood perfectly still when he sang and made fow gestures. Mancini, a well-qualified judge, wrote: "His voice was thought a marvel because it was so perfect, so powerful, so sonorous, so rich in its extent, both in the high and in the low registers that its equal has never been heard in our times." Another critic records that "he had a voice proportioned to his gigantic stature, extending beyond the ordinary compass near one octave, in notes equally clear and sonorous."

Farinelli went to Madrid in $\mathbf{1 7 3 7}$ for a brief visit; he remained there twenty-two years. When he arrived the King was suffering from apparently incurable depression. The queen arranged to have Farinelli sing in a chamber next to the king's, and the unhappy monarch was so much cheered by the songs that he at once engaged him as permanent court singer at a yearly salary of some $\$ 15,000$, with a coach and equipage to boot. Every honor was heaped upon him. His only duties appear to have been to sing 
the same four tender ditties in the royal presence every evening. A statistician would probably take an interest in calculating that Farinelli must have rendered his little program some $\mathbf{3 6 , 0 0 0}$ times before death removed King Philip from his earthly kingdom and thereby afforded Farinelli a wider and more stimulating field for his talents.

These talents must have been considerable, for Ferdinand, Philip's successor, not only appointed Farinelli the manager of the court opera, but also made him his confidential adviser in matters political and diplomatic - a post seldom, if ever, held by a eunuch in an occidental court. Wealth and honors of every kind were heaped upon him, but he performed his duties so skilfully and bore himself with such discretion and tact as to arouse no jealousy or dislike in those with whom he was thrown. His cup of prosperity was running over when in $\mathbf{1 7 5 9}$ the king died.

Unfortunately for Farinelli, the new king either could not or would not retain him in his service and the old singer had to withdraw permanently from Spain. He decided to spend his declining years in Bologna and there, in a villa purchased with the profits of his seasons in England and appropriately dubbed by him "English Folly," Dr. Burney found him in 1771, living in luxury and ruminating regretfully on the glories of his past. He died in 1782 .

Almost exactly contemporary with Farinelli and of equal artistic fame was Caffarelli, who was born in Bari in 1703 . He, too, studied with Porpora and the story bas been told countless times of how the wise master kept him working for several years on a few pages of vocalises and then dismissed him, saying "Go; I can teach you nothing more. You are already the best singer in Europe." Caffarelli made his début in Rome in 1724 in the role of a woman. His remarkable artistic gifts brought him an instantaneous triumph and within a few years had placed him in the very front rank of Italian singers. All the capitals of Europe knew and admired his lovely art.

Porpora, the teacher of Farinelli, judged Caffarelli to be the greatest singer Italy had produced. Handel, too, had a high opinion of his quality, and though he usually insisted on having his music sung just as he wrote it, occasionally permitted Caffarelli to change it to suit his own taste. Handel wrote for him his famous "Largo" (the opening air in his opera, "Serse") "in a clear and majestic style," as Dr. Burney put it prophetically, "out of reach of time and fashion." Another great man, David Garrick, heard him sing in church so late as 1764 and wrote home: 
"The principal part was sung by the famous Caffarelli, who, though old, has pleased me more than all the aingers I have heard. He touched me; and it was the first time I have been touched since I came to Italy." Dr. Burney heard him sing seven years later than this and found his voice still enjoyable. Certainly, Caffarelli must have been a great artist.

As a singer Caffarelli may have been even the superior of Farinelli, but as a man the comparison was altogether in Farinelli's favor. Farinelli was a man of refined tastes and elegant manners; Caffarelli was Leporello masquerading as Don Giovanni. Many tales are told of his conceit, his parsimony and his amorous adventures. Once, when in Paris, he sang for Louis $\mathrm{XV}$, who, though usually indifferent to music, took so much pleasure in his singing that the next day he sent him a handsome snuff-box as a token of his royal approval. The singer examined the box, then tossed it contemptuously on the table, saying, "I have already a drawerful of snuff-boxes quite as handsome as that. The king might at least have sent me his picture." "But that," replied the messenger, "is an honor accorded to ambassadors only." "Indeed!" cried the singer, "but all the ambassadors in the world would not equal one Caffarelli!"

When he first ang for the Prince of Savoy, the Prince praised him highly, but added that when he should sing for the princess, his daughter, she might find him inferior to her favorite singer, Farinelli. Caffarelli replied confidently, "To-night she shall hear two Farinellis."

Throughout his long career Caffarelli received large fees for his services, though they were never so large as he felt he merited. Being a thrifty soul, he accumulated a substantial property with which he purchased an estate that carried with it the title of "Duke of Santo Dorato." It was there that Caffarelli made his home and died in 1783. It is said that the descendants of some member of his family still possess the estate and the title.

With Farinelli and Caffarelli the evirati may be sajd to have reached the zenith of their artistic worth and popular vogue. The large fees paid to the favorites among them influenced the conscienceless parents and teachers of many talented boys with good voices to prepare them for what they hoped would be remunerative careers. Occasionally their hopes were realized, but much more often the boys did not fulfil their early promise and had nothing to compensate for the irremediable injury done them.

From first to last the whole business was Italian, flourishing most luxuriantly in southern Italy, with Naples as headquarters, 
and in the Papal States. In theory the surgical operation was illegal; but in practise it was winked at. Dr. Burney reports that wherever he made inquiries about it the natives assured him that there was no violation of the law, but that everywhere else it was a dead letter. Another traveler quotes a sign he saw over a door in Naples, which read, "Qui si castra a basso prezso" (castrating done here at bottom prices).

Of course the castrato figured prominently in the scandalous memoirs of the time. Here we are concerned with his musical history only.

Of the castrati of the generation succeeding that of Caffarelli the most memorable was Guadagni. He first came into prominence by reason of his admirable performance of Handel's "Messiah" and "Samson" in English under the composer's own direction. It is doubtful whether before this any castrato had ventured to sing publicly in any language but his own. Guadagni's voice, at first a counter-tenor, developed into a lovely mezzo-soprano. He was a man of remarkable intelligence and ambition and of such striking histrionic gifts that, under the tutelage of David Garrick, he became one of the best actors in Europe. He created Gluck's "Orfeo" in its Italian version, and it is said that whenever he sang "Che fard" in Vienna the entire audience dissolved in tears. Dr. Burney admired him with reservations, thinking him most interesting in unaccompanied songs and in the spinning out of his tones. Guadagni's temper was extremely capricious and irritable. He never would repeat an air or respond in any way to applause. His enemies, and he had many, would often applaud him excessively in order to ruffle his temper and to arouse a hostile feeling in the audience, whose approval he feigned to scorn.

The most meritorious of the male sopranos that came after Guadagni was probably Pacchierotti (1744-1821). After brilliant successes in Italy he came in 1778 to London, where he entirely justified his great continental reputation. Lord MountEdgcumbe described Pacchierotti as "decidedly the most perfect singer it ever fell to my lot to hear." His voice was an extensive soprano, full and sweet in quality. He was master of every style; his technique was flawless. In an epoch when skill in embellishment was highly prized, he was so fertile in invention that he never sang a piece twice in just the same fashion. If he may be said to have been more effective in one style of singing rather than in another, he excelled in the rendering of pathetic airs. Once while he was rehearsing he noticed that the orchestra had 

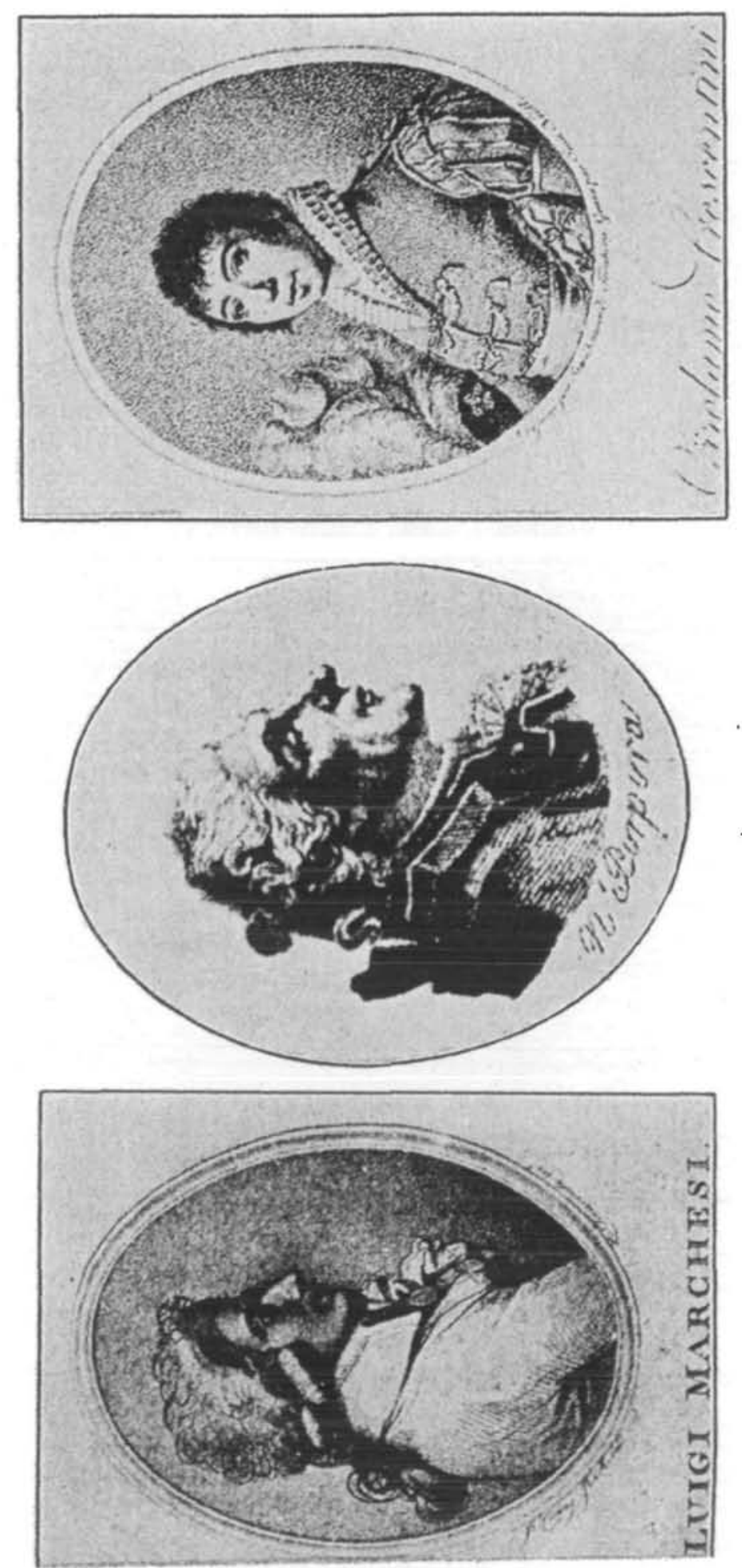
$\checkmark$

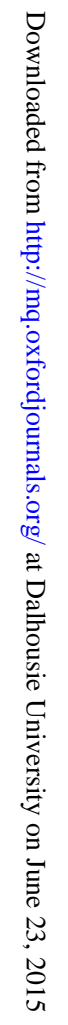


ceased to accompany him. He, too, stopped and asked the leader the cause of the orchestra's silence. "We cannot play because we are weeping," was the reply. Pacchierotti was an indifferent actor, and for this reason won his greatest successes on the concert stage. Lord Mount-Edgcumbe was so lucky on one occasion as to hear him sing an air by Haydn with the composer himself at the pianoforte.

Scarcely less famous than Pacchierotti was Luigi Marchesi (1756-1829), who made his début in Rome in 1774 in a feminine role. Soon he became famous all over Europe, although he did not reach London till 1788, when he created a fine impression of his powers in Sarti's "Giulio Sabino." Dr. Burney thought him "not only elegant"und refined to an unusual degree, but often grand and full of dignity." The brilliancy of his technique enabled him to achieve extraordinary effects in bravura passages. Towards the end of his career his professional association with the young Catalani did much to develop the security and facility of her astonishing voice.

Marchesi had exalted ideas concerning his own talent and was especially exacting as to the character of his opening air in all his operatic roles. He was partial to the color red, and when the curtain first rose was usually discovered standing on a rock, clad in a robe of his favorite hue. In answer to a blast from a trumpet he would utter his first notes, remarking that his ears had heard the call. Then he would descend slowly and majestically from his rocky eminence, and after a few lines of recitative enter upon the air, which generally dealt with the havoc that unhappy love had wrought in his mighty heart.

Still another noted murico was Crescentini (1766-1846). One of his most famous parts was that of Romeo in Zingarelli's opera. His performance in the final scene is said to have been so eloquent as to draw tears from the eyes of the great Napoleon himself. An amusing tale is told of how once, just before the rise of the curtain on a new opera, Crescentini, who was small in stature, observed that one of the minor singers, an unusually tall man, was more resplendently dressed than he himself, the "primo uomo." He was much disturbed and absolutely refused to begin the performance until the tall man had exchanged costumes with him. The exchange finally effected, Crescentini, in perfect conceit with himself, played the whole performance in a costume much too large for him, while his unfortunate colleague had to struggle through his part clad in a tunic hardly sufficient to cover his nakedness. Fetis wrote of Crescentini: "Nothing could ex- 
ceed the suavity of his tones, the perfect taste of his ornaments, or the large style of his phrasing."

The arrival of the nineteenth century marks the passing from fashion of the castrati. Velluti (1781-1861), the last whose name is worth remembering, made his debut in 1800 . For twentyfive years he toured the continent successfully and in 1825 came to London. No musico had been heard there in a quarter of a century and the public listened to this survivor of another artistic epoch with scarcely more than respectful attention. The opera Velluti selected for his first appearance was "Il Crociato in Egitto" by Meyerbeer and in the cast with him was the youthful and unknown Maria Garcia (Malibran). His voice was no longer fresh, but the older generation took pleasuse in hearing again the kind of singing that in their youth had seemed so lovely. The younger dilettanti, on the contrary, thought it old-fashioned, silly and a perversion of a beautiful art. Mendelssohn, who heard Velluti in 1829, could not listen without a feeling akin to repulsion and this attitude of mind soon became the attitude of all Europe.

Velluti had no successors worthy of the name. The young Italian compaser, Gioachino Rossini, a sane, red-blooded genius, could find no place in his operas for sexless heroes. To him the virile personality and art of Manuel Garcia ware worth a thousand male sopranos. It was Rossini's scorn of the whole tribe that drove the castrato from the operatic stage. Henceforth the tenor was the King of Singers.

The male soprano kept his place in the choirs of Italy as late as the end of the nineteenth century, long after his operatic brother had left the stage forever. It was Leo XIII that banished him finally from St. Peter's and soon after this coup de grdce he piped his last treble note and was heard no more.

There is really nothing to regret in the extinction of this emasculate race, the mere toleration of whom seems to denote a perverted musical taste, but there is no denjing that their artistic claims were recognized by thousands of sincere musiclovers, including composers as significant as Handel, Scarlatti, Porpora, Hasse and the early Gluck. For this reason students of the history of singing and of serious opera will always be concerned with the part played by the male sopranos in the development of the art of singing.

How did their voices sound? Would that we had phonographic records of some of their famous airs - of the four, for instance, that Farinelli used to sing for the King of Spain, or of 
Guadagni': "Che fard"l The critics of their time took them so much for granted that they tell us very little that is informing about the quality or volume of their voices. The Italians, who knew them best, wrote more about their scandalous adventures than they did about their art. The French, who were busy developing a school of opera in harmony with their national characteristics, paid but scant attention to Italian opera and its performers. Rousseau, naturally enough, could discover no merit whatsoever in these childless men. The English dilettanti, to whom the exotic in music has always made an appeal, received the male sopranos with great cordiality and during the entire eighteenth century cherished them, petted them and provided them liberally with the wherewithal to purchase villas and estates to which to retire in their old age. From such annalists as Dr. Burney, Sir John Hawking and Lord Mount-Edgcumbe one derives much valuable and curious information regarding the castrati and their art. In some of the German capitals, especially in Vienna, the home of Metastasio, opera soria acquired a firm footing and the castrato was well known and liked. One German connoisseur, Wilhelm Heinse, wrote that "nothing in all music is 80 beautiful as the fresh young voice of a castrato; no woman's voice has the same firmness, strength and sweetness."

I am inclined to believe that in this sentence we find the erplanation of the long popularity of the castrato. We all recognize the loveliness of the boy's voice at its best; if we can imagine the increase in volume that must have come with the normal development of the physical powers, and also all that prolonged study and the highly focussed effort of will and intelligence on the part of an ambitious and talented musician could accomplish in developing the expressive resources of such a voice, we may be able to form some idea of the bel canto of Caffarelli, Guadagni and Pacchierotti.

The vocal range of the musioo soems not to have been remarkable for its extent, but his facility in execution was stupendous. Composers and singers strove ever to invent new feats of vocal jugglery with which to bewilder and delight their public. The flexibility of Parinelli's voice was so highly developed that the violins in the orchestra could not follow him in his flights. Caffarelli was renowned for the perfection of his trill and was the first to embellish his airs with rapid chromatic scales. Virtuosity came to be the chief test of a singer's merit.

The Golden Age of the castrato was the first half of the eighteenth century, with Handel devoting his great genius and energy 
to the creation and production of opera seria. His operas were cast in a strictly conventional form, ${ }^{1}$ but Handel was a great enough man to rise superior to them and to create music some of which survives in the repertory of to-day. Those that came after him -I cannot call them his successors-were no greater than their singers and their public and opera soria deteriorated into the pasticcio and its hopeless inanities. The castrato had not the force to stem the downward tendency and as the years went by fell into disrepute in company with the opera that nourished him.

Just as in the boy's voice we note the lack of the passion that stirs our deeper natures, so the voice of the male soprano must have been similarly deficient. In this we find one reason for the superficiality, the artificiality of all the music, except some of Handel's, that was written for the castrati. But the eighteenth century did not seek sincerity and profound feeling in any kind of art so much as it prized a facile technique and elegance of style. Porpora, "the Patriarch of Harmony," and Hasse, who were thought by many to be the equals and by some to be the superiors of Handel-their innumerable operas all sleep in deserved oblivion and with them slumber Jommelli's forty-two "master-pieces," though Jommelli, even prior to Gluck at least deliberately attempted to break away from the rigid conventionality of the opera seria of his time. Metastasio, who wrote twenty-nine dramas, some of which were set to music thirty or forty times, is now only a name in musical history. He used to speak of Farinelli as his "twinbrother," and he was right: both of them were typical of their era. They could have flourished in no other, but in their own they stood out as men of talent, exemplars of what was best in their respective artistic fields. Handel, being a real genius, cannot be grouped with them, but either Porpora or Hasse can be selected to complete the representative trio of librettist, composer and primo uomo of opera seria in the eighteenth century.

It was often said, especially, by German writers, that the castrati could not act, but there is no reason to believe that they

IBis aries mostly constructed according to the da capo convention, fall almost invariably into one of the five following categories: I Aria cantabilo pathetic melady. offering opportunity for ormamentation at the discretion of the singer, with a simplo orchertral eccompaniment.

II Aria di Portamento-low in movement-rtrong in rhythm-with sutained notes-fer chances for embelliohment-Gowing but redate accompaniment.

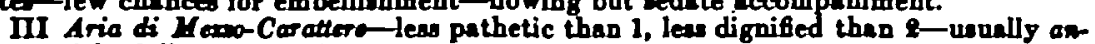
dasto rich full accompaniment.

IV Aria porlanto-dedamatorylopportunity for emotion and paesion-elabarate sceompaniment.

$\checkmark$ Aria di Bramro-allegra, with opportunity to display agility.

There was alo the aria dinilarions where the voice imitated the execution of trumpeter futes or violini-echo cong. 

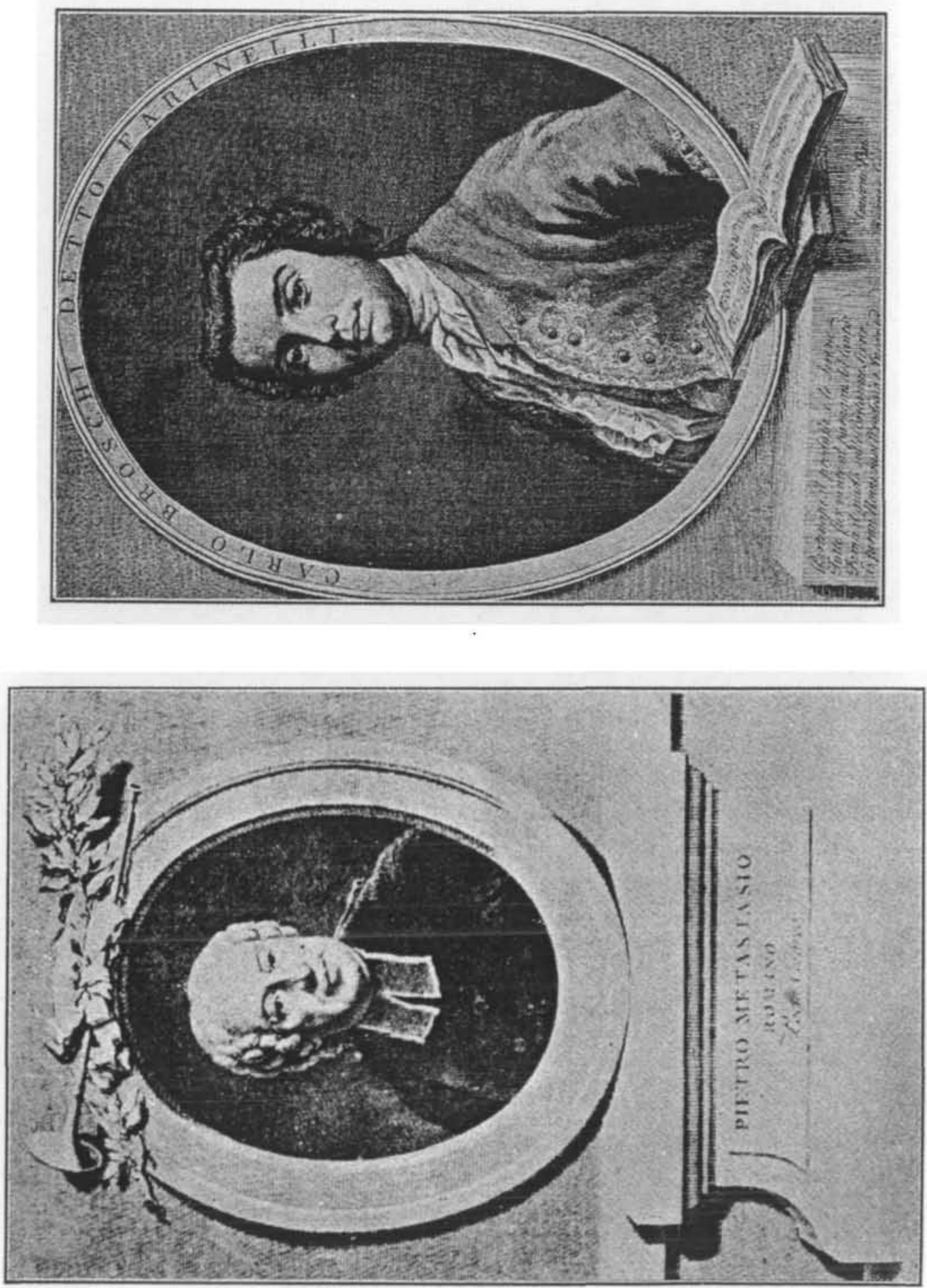
were, on the average, less proficient in this respect than their successors, the tenors. We have seen above how deeply Guadagni and Crescentini could move their audiences by their histrionic skill. Of Nicolini, a male soprano of Queen Anne's time, Sir Richard Steele wrote:

I have seen him advance with such greatness of mien and air as seemed to fill the stage and at the same time command the attention of the audience with the majesty of his appearance. His action was so significant that a deaf.man might go along with him in the sense of the part he acted.

In length of professional activity the male soprano exceeded all other singers. Chosen for his career at an early age and deprived of all normal ambitions outside of his particular sphere, he concentrated all his energy on the development and preservation of his voice. In consequence, he oftened retained his power to please his hearers for thirty or even forty years. Caffarelli was more than sixty when he touched the heart of Garrick by his singing, and Matteucci, another musico, still sang agreeably at eighty.

We may disparage a musical taste that could admire so unnatural a prodigy as a male soprano, but we cannot deny that not a few of these strange beings were serious, well-trained musicians, for whom some really great composers wrote much excellent music. By precept and example they helped, when the art of singing was still young, to develop and perfect the laws of vocal technique. Last, but not least, their art gave untold pleasure to several generations of music-lovers and did its share towards laying the foundations for the broader and nobler vocal art of the nineteenth century. 